\title{
Implementation of Transformational Leadership on Lecturer Satisfaction and Performance in FKIP Darma Agung University Medan
}

\author{
Fransiskus Gultom Alim Perangin-angin Selamat Karo-Karo \\ Darma Agung University Medan, Indonesia
}

\begin{abstract}
Implementation of transformational leadership to job satisfaction and lecturer performance at FKIP Darma Agung University Medan is very necessary to be done by a leader in an institution or organization. Research on the implementation of transformational leadership on job satisfaction and lecturer performance at FKIP Darma Agung University Medan has been conducted. This research is in the form of an empirical study at FKIP Darma Agung University Medan. The purpose of this study is to look at the implementation of transformational leadership on job satisfaction and lecturer performance at FKIP Darma Agung University Medan. From the results of the study, the role of transformational leadership becomes very important in the success of an organization for the performance of its subordinates. This research is in the form of a descriptive study with a sample of 60 permanent lecturers from FKIP Darma Agung University Medan. The technique used in conducting this research was to give a questionnaire to all respondents to be filled and collected. From the results of tabulation of research data on work satisfaction indicators obtained by $81.36 \%$ and for performance indicators obtained by $82.40 \%$. From the results of this study, it was concluded that the implementation of transformational leadership on job satisfaction and lecturer performance at FKIP Darma Agung University Medan was very good.
\end{abstract}

Keywords: implementation of transformational leadership, job satisfaction and performance.

DOI: $10.7176 / \mathrm{JEP} / 11-19-10$

Publication date:July $31^{\text {st }} 2020$

\section{Introduction}

Leadership is a pattern and method applied by a leader in guiding and directing his subordinates. Organizations need reformist leaders who are able to be the driving force of organizational transformation. Leadership is the process of encouraging and helping others to work enthusiastically toward goals (Mintzberg in Davis, et al., 1996). In organizational life, leaders have a very important role. All good activities ranging from planning, carrying out supervision to setting goals are determined by the leadership. Forward progress of organizational life depends on the ability of leaders in controlling people, equipment, resources and other resources.

Leaders play an important role in social and state life in groups or organizations. Leadership becomes an opening for organizational success (Kartono, 2008). In any field and in any country the leader is needed because his function is to lead, but all this is adjusted to the characteristics of the group and its subordinates, and besides that it really depends on the times. A leader who is strong and has high loyalty and dedication will greatly influence the progress and development and survival of the organization. For this reason, transformational leadership is needed from a leader so that each subordinate can work calmly and with high enthusiasm. In large-scale organizations, leaders are seen as a very decisive element in the process of developing the business world (Lok and Crawford, 2004).

The quality of leaders is often considered as the most important factor in the success or failure of an organization (Menon, 2002), as well as the success or failure of an organization, both business and public oriented, usually perceived as the success or failure of a leader. So important is the role of the leader that the issue of the leader becomes the focus that attracts the attention of researchers in organizational behavior. According to Scarnati (2002), leaders have a very large influence on organizational success. Leaders play a key role in formulating and implementing organizational strategies. Commitment in the organization will make the worker give the best to the organization where he works. It was even stated that leaders who are committed to high organizations will tend to be happy to help, can work together (Su'ud, 2000). Congruence between leadership, norms and organizational culture is seen as a key prerequisite for the successful achievement of organizational goals (Yulk, 1989). Although in relation to leadership theory in North America it is limited from other countries (Lapin, 1990).

Job satisfaction and performance is a theory or practical concept that is very important, because it is an impact or the result of the effectiveness of performance and success at work. Job satisfaction and low performance in organizations is a series of decreased task performance, increased absenteeism, and decreased organizational morale. Whereas at the individual level, job satisfaction and performance are related to a great desire to get out of work. Transformational leadership refers to the work performance of leaders measured based on standards or criteria set by the Institute. Management to achieve a very high leader performance, especially to improve the overall performance of the Institute. Factors that influence transformational leaders include organizational strategy 
(the value of short-term and long-term goals, organizational culture and economic conditions) and individual attributes including abilities and skills. Transformational leadership from a leader can increase job satisfaction and the performance of his subordinates in the organization. According to Fuad Mas'ud (2004), the progress and success of an organization is very dependent on the leader. The extent to which the leader is able and willing to work hard, creative, innovative, loyal, disciplined, honest and responsible will determine the organization's achievements. Therefore to find out how far the leader works, the leader needs to evaluate his performance. Leaders must have the ability in leadership. Without ability, people will not want to listen. Because leaders must be able to arouse the respect of others.

There are several types of differences in transformational leadership and ways of working between the various individuals and departments within the organization which make it difficult to coordinate parts of the organization effectively, namely: a) Differences in orientation towards specific goals. Members from different departments develop their own views on how to achieve good organizational interests; b) Difference in time orientation. The leader will pay more attention to problems that must be solved immediately in a short period of time. The research and development section is more involved with long-term problems; c) Differences in interpersonal orientation. Transformational leadership activities require rapid communication and decision making so that the process is smooth, while the research and development section may be more relaxed and everyone can express their opinions and discuss with one another; and d). Differences in structural formalities. Each type of unit in the organization has different methods and standards for evaluating the program against its objectives and to reward services to its subordinates. The success or failure of an organization is usually perceived as the success or failure of a leader.

According to Kohl, et al., (1995), leaders have an enormous influence on organizational success. Leaders play a key role in formulating and implementing organizational strategies.

\section{Research Methods}

In this paper, the method used is through primary data. Primary data were obtained by distributing questionnaires addressed and filled out by all lecturers at FKIP Darma Agung University Medan. The total number of lecturers in the FKIP Darma Agung University Medan environment was 60 people, and at the same time used as a sample. This research is descriptive research.

\section{Results and Discussion}

Based on the results of research and data processing that has been done in the effect of the implementation of transformational leadership on job satisfaction and performance at FKIP Darma Agung University Medan, it can be discussed as follows:

\section{Job Satisfaction}

Based on the results of research and tabulation of data that has been done on indicators of job satisfaction, can be seen in Table 1 below.

Table 1. Tabulate the number of responses in filling out the questionnaire on Job Satisfaction Indicators

\begin{tabular}{|c|l|c|}
\hline No & \multicolumn{1}{|c|}{ Job Satisfaction Indicator } & Number of people \\
\hline 1 & Loyalty & 51 \\
\hline 2 & Responsible & 49 \\
\hline 3 & Cooperation & 50 \\
\hline 4 & Honesty & 48 \\
\hline 5 & Accuracy & 47 \\
\hline \multicolumn{2}{|r|}{ Total } & $\mathbf{2 4 5}$ \\
\hline
\end{tabular}

From Table 1 above on the indicators of job satisfaction with respondents as many as 60 people, it was obtained who answered Loyalty as many as 51 people, who answered Responsibility as many as 49 people, who answered cooperation as many as 50 people, and who answered Honesty as many as 48 people and Accuracy as many as 47 people. From the overall results obtained an average of 49 people, meaning as many as 11 people who did not give a response. Therefore, from the results obtained, it can be said that the implementation of transformational leadership on job satisfaction indicators can be said to be good.

Based on the results of research and tabulation of data that has been done on indicators of job satisfaction, then the percentage of respondents can be seen in Table 2 below. 
Table 2. Percentage of the number of responses in filling out the questionnaire on Job Satisfaction Indicators

\begin{tabular}{|c|l|c|}
\hline No & \multicolumn{1}{|c|}{ Job Satisfaction Indicator } & Percentage (\%) \\
\hline 1 & Loyalty & 85.00 \\
\hline 2 & Responsible & 81.67 \\
\hline 3 & Cooperation & 83.33 \\
\hline 4 & Honesty & 80.00 \\
\hline 5 & Accuracy & 78.33 \\
\hline \multicolumn{2}{r|}{ Total } & $\mathbf{4 0 8 . 3 3}$ \\
\hline & Average & $\mathbf{8 1 . 6 7}$ \\
\hline
\end{tabular}

From Table 2 above on the indicators of job satisfaction with respondents as many as 60 people, obtained a percentage that answered Loyalty of $85.00 \%$, who answered Responsibility of $81.67 \%$, Cooperation of $83.33 \%$, Honesty of $80.00 \%$ and Accuracy of $78.33 \%$. From the overall results, the average percentage was $81.67 \%$, meaning that only $18.33 \%$ did not give a response.

This implies that job satisfaction can be improved if the implementation of transformational leadership continues to be improved. Implementation of transformational leadership is a variable that has an influence in relation to job satisfaction. This shows that the implementation of transformational leadership greatly influences job satisfaction. The results of data tabulation and data processing in this study reinforce the results of empirical research from Griffin (1980) and Mc Cue, et all., (1997) which states that there is a correlation between transformational leadership and job satisfaction. Therefore, from the results obtained, it can be said that the implementation of transformational leadership on indicators of job satisfaction can be said to be good.

For more details, this can be seen in Fig. 1 below.

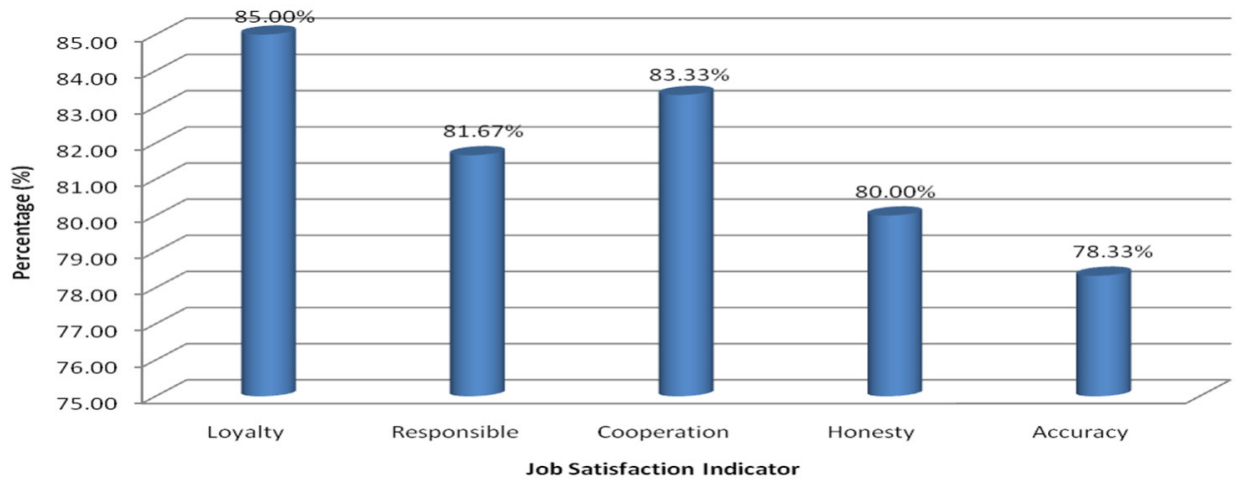

Fig. 1. Transformational leadership through job satisfaction indicators

From Fig. 1 above, loyalty is obtained at $85.00 \%$, responsibility is $81.67 \%$, cooperation is $83.33 \%$, honesty is $80.00 \%$, and accuracy is $78.33 \%$. Therefore from the results obtained, it can be said that the implementation of transformational leadership on indicators of job satisfaction can be said to be good.

The Performance

Based on the results of research and tabulation of data that has been done on performance indicators, can be seen in Table 3 below.

Table 3. Tabulate the number of responses in filling out the questionnaire on the Performance Indicators

\begin{tabular}{|c|l|c|}
\hline No & \multicolumn{1}{|c|}{ Performance Indicator } & Number of people \\
\hline 1 & Punctuality & 49 \\
\hline 2 & Use office equipment well & 48 \\
\hline 3 & Obedience & 50 \\
\hline \multicolumn{2}{r}{ Trotal } & $\mathbf{1 4 7}$ \\
\hline & Average & $\mathbf{4 9}$ \\
\hline
\end{tabular}

From Table 3 above on the performance indicators of the respondents as many as 60 people, obtained that answered the punctuality as many as 49 people, who answered Using office equipment well as many as 48 people, and who answered obedience as many as 50 people. From the overall results obtained an average of 49 people, meaning that only 11 people who did not give a response. Therefore, from the results obtained, it can be said that 
the effect of implementing transformational leadership on performance indicators can be said to be good.

Based on the results of research and tabulation of data that has been done on performance indicators, then the percentage of respondents can be seen in Table 4 below.

Table 4. Percentage of the number of responses in filling out the questionnaire on the Performance Indicators

\begin{tabular}{|c|l|c|}
\hline No & \multicolumn{1}{|c|}{ Performance Indicator } & Percentage (\%) \\
\hline 1 & Punctuality & 81.67 \\
\hline 2 & Use office equipment well & 80.00 \\
\hline 3 & Obedience & 83.33 \\
\hline \multicolumn{2}{r|}{ Total } & $\mathbf{2 4 5}$ \\
\hline & Average & $\mathbf{8 1 . 6 7}$ \\
\hline
\end{tabular}

From Table 4 above on the performance indicators of the respondents as many as 60 people, the percentage obtained that answered Timeliness was $81.67 \%$, which answered Using office equipment well amounted to $80.00 \%$, and who answered Compliance was $83.33 \%$. From the overall results obtained an average percentage of $81.67 \%$, meaning that only $18.33 \%$ did not give a response.

This implies that performance can be improved if the implementation of transformational leadership continues to be improved. Transformational leadership is a variable that has an influence in relation to performance. Therefore, from the results obtained, it can be said that the implementation of transformational leadership on performance indicators can be said to be good.

For more details, this can be seen in Fig. 2 below.

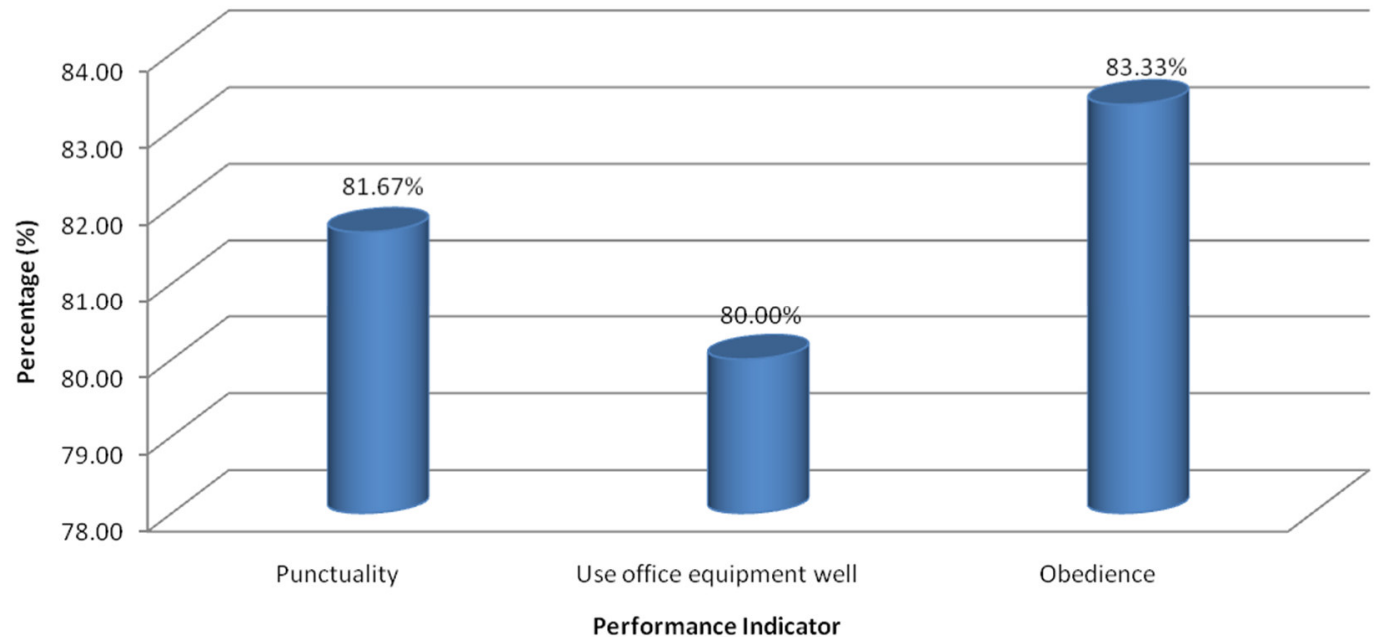

Fig. 2. Transformational leadership through performance indicators

From Fig. 2 above, the percentage of timeliness is obtained at $81.67 \%$, the percentage of Using office equipment is well at $80.00 \%$, and the Obedience percentage is $83.33 \%$. Therefore, from the results obtained, it can be said that the implementation of transformational leadership on performance indicators can be said to be good.

From the overall indicators carried out, overall the indicators carried out can be seen in Table 5 below.

Table 5. Tabulate the number of responses in filling out the questionnaire for all indicators

\begin{tabular}{|c|l|c|}
\hline No & \multicolumn{1}{|c|}{ Indicator } & Number of people \\
\hline 1 & Job satisfaction & 49 \\
\hline 2 & The performance & 49 \\
\hline \multicolumn{2}{|r|}{ Total } & $\mathbf{9 8}$ \\
\hline \multicolumn{2}{|r|}{ Average } & $\mathbf{4 9}$ \\
\hline
\end{tabular}

From Table 5 on the overall indicators that have been carried out on respondents as many as 60 people, it was obtained that answered on the job satisfaction indicators as many as 49 people and on the performance indicators as many as 49 people.

Based on the results of research and tabulation of data that has been done on indicators of job satisfaction and performance, then the percentage of respondents can be seen in Table 6 below. 
Table 6. Percentage of the number of responses in filling out the questionnaire for all indicators

\begin{tabular}{|c|l|c|}
\hline No & \multicolumn{1}{|c|}{ Indicator } & Percentage (\%) \\
\hline 1 & Job satisfaction & 81.67 \\
\hline 2 & The performance & 81.67 \\
\hline \multicolumn{2}{|r|}{ Total } & $\mathbf{1 6 3 . 3 3}$ \\
\hline \multicolumn{2}{|r|}{ Average } & $\mathbf{8 1 . 6 7}$ \\
\hline
\end{tabular}

From Table 6 on the overall indicators that have been carried out on respondents as many as 60 people, obtained a percentage that answered the indicators of work satisfaction by $81.67 \%$ and performance by $81.67 \%$.

An overview of these indicators can be seen in Fig. 4 below.

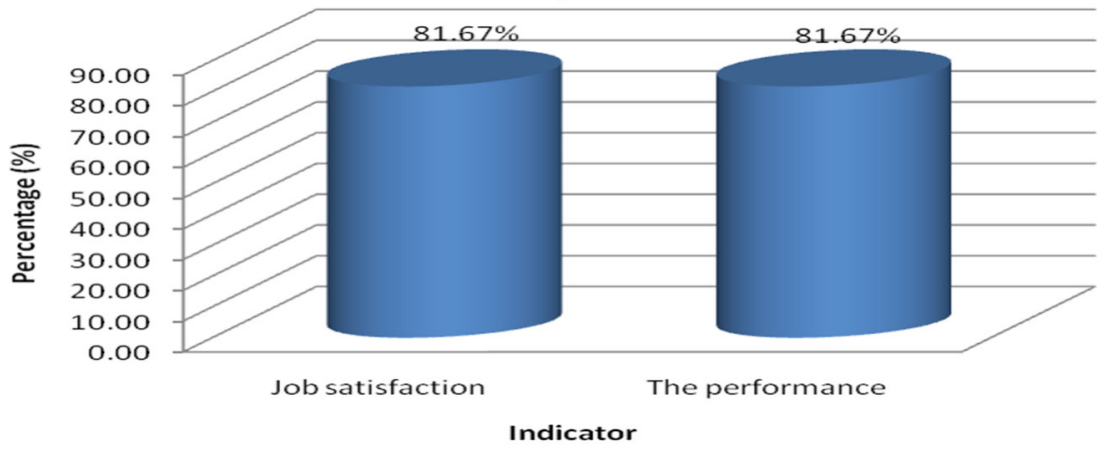

Fig. 4. Percentage of respondents in implementing transformational leadership through indicators of job satisfaction and performance

From Fig. 4 above, the percentage of job satisfaction was $81.67 \%$ and the performance was $81.67 \%$.

Therefore, from the results obtained, it can be said that the implementation of transformational leadership on indicators of job satisfaction and performance can be said to be good.

\section{Conclusion}

From the results of the discussion above, several conclusions can be drawn, including:

1. In the implementation of transformational leadership through job satisfaction obtained by $81.67 \%$. This implies that job satisfaction at FKIP Darma Agung University Medan is good.

2. In the implementation of transformational leadership through performance obtained by $81.67 \%$. This implies that the performance at FKIP Darma Agung University Medan is good.

\section{References}

Davis, Keith. Newstrom, and John W., 1996. Human Behavior at Work: Organizational Behavior $\left(7^{\text {th }}\right.$ Ed.)

Fuad Mas'ud. 2004. The Organizational Diagnosis Survey Concept and Application, UNDIP, Semarang.

Griffin, Ricky W., 1980. "Relationships Among Individual, Task Design, and Leader Behavior Variables", Academy of Management Journal, Vol. 23, No. 4, 665-683.

Kartono Kartini, 2008. Leaders and Leadership, PT. Raja Grafindo Persada, Jakarta.

Kohl, et all., 1995. "The Effect of Transformational Leadership on Teacher Attitudes and Student Performance in Singapore", Journal of Organizational Behavior, 16: 319-333.

Lapin, Laurence. 1990. Statistics for Modern Business Decisions $5^{\text {th }}$ Edition, Harcourt Brace Jovanovich, Publishers.

Lok \& Crawford. 2004. "The Effect of organizational culture and leadership style on job satisfaction and organizational commitment across-National Comparison", The Journal of Management Development, Vol. 23, No. 4, 321-337.

Mc Cue, Clifford, et all., 1997. The Relationship Between Job Satisfaction and Performance. Public Productivity and Management Review, Vol 41, No.2, pp 160-191.

Menon, Maria E., 2002. Perceptions of Pre-Service and In-Service Teachers Regarding the Effectiveness of Elementary School Leadership in Cyprus. The International Journal of Educational Management, 16 February, p.91-97.

Scarnati, James T.,2002. Leader as Role Models:12 Rules. Career Development International, 7 Maret, p.181-189.

Su'ud. 2000. Social Perceptions About Credibility of Leaders, Synergy in Business and Management Studies, vol.3, No.1. Pp. 51-65.

Yulk, Gary A. 1989. Managerial Leadership: A Review of Theory and Research. Journal of Management, Vol 15, No.2, 251-289. 